\title{
Influence of urban air pollution on the population in the Klang Valley, Malaysia: a spatial approach
}

\author{
Siti Haslina Mohd Shafie ${ }^{1^{*}} \mathbb{D}$, Mastura Mahmud', Suzani Mohamad², Nor Lita Fadilah Rameli², \\ Ramdzani Abdullah² and Ahmad Fariz Mohamed ${ }^{3}$
}

\begin{abstract}
Background: Urban air pollution resulting from economic growth as well as urbanization impacts the health of inhabitants. This study aims to examine the spatial distribution of particulate matter $\left(\mathrm{PM}_{10}\right)$ and the risk of exposure for the population in the Klang Valley, an urban conglomeration centred in Kuala Lumpur, Malaysia.

Methods: The inverse distance weighted (IDW) interpolation technique in the ArcGIS platform was used to map the air quality from five air monitoring stations. Spatial statistics of the Global Moran's / Spatial Autocorrelation and Optimized Hot Spot Analysis were used to estimate the spatial clustering of $\mathrm{PM}_{10}$. The population-weighted exposure level (PWEL) technique was used to calculate the population density susceptible to $\mathrm{PM}_{10}$ and the AirQ+ model was applied to estimate the proportion of the adult population at risk of chronic bronchitis due to long-term exposure to $\mathrm{PM}_{10}$ concentrations in the Klang Valley.

Results: The highest annual mean $\mathrm{PM}_{10}$ concentrations at the Klang station ranged between 80 and $100 \mu \mathrm{g} / \mathrm{m}^{3}$ from 2000 to 2009 and exceeded the New Malaysia Ambient Air Quality Standard (NMAAQS) and the World Health Organization Air Quality Guidelines (WHOAQG) levels of 40 and $20 \mu \mathrm{g} / \mathrm{m}^{3}$, respectively. The Moran's / results indicated that the statistically significant clusters of high $\mathrm{PM}_{10}$ in Klang present a health risk to the local community. The PWEL results showed that levels of $\mathrm{PM}_{10}$ in Petaling Jaya exceeded the WHOAQG limits, potentially posing a health risk to the highdensity population. The AirQ+ model found Klang to be a significantly high-risk area for chronic bronchitis among the adult population with 804,240 people (with a relative risk of 1.85) in 2009.

Conclusion: These high-risk values are due to rapid urbanization and high motor vehicle usage in the Klang Valley and therefore the impact of $\mathrm{PM}_{10}$ on the population needs to be reduced. This situation should be taken seriously by the Department of Environment and Kuala Lumpur City Hall in addressing air pollution issues through stricter rules on emissions and implementing low-carbon policies to improve the well-being of residents.
\end{abstract}

Keywords: Population, Urban air pollution, Spatial distribution, $\mathrm{PM}_{10}$, Adult chronic bronchitis risk

*Correspondence: sitihaslina87@gmail.com

${ }^{1}$ Centre for Research in Development, Social and Environment (SEEDS),

Faculty of Social Sciences and Humanities, Universiti Kebangsaan

Malaysia, Bangi, Selangor, Malaysia

Full list of author information is available at the end of the article

\section{Introduction}

Rapid urbanization is stimulated by population growth and increases in economic activities in city centres. The increase in air pollutants released from various sources causes the air quality to deteriorate, which is detrimental to the health of individuals. Air pollution in Malaysia is largely caused by point sources, specifically industrial manufacturing and energy generation, as well as from 
mobile sources (motor vehicles) and open burning activities (DOE 2017). These sources release a variety of toxic gases, such as carbon monoxide (CO), nitrogen dioxide $\left(\mathrm{NO}_{2}\right)$, sulphur dioxide $\left(\mathrm{SO}_{2}\right)$, and ozone $\left(\mathrm{O}_{3}\right)$, as well as suspended particles of less than $10 \mu \mathrm{m}\left(\mathrm{PM}_{10}\right)$. The total pollutants in 2017 consisted of 2,123,281 metric tonnes of $\mathrm{CO}$, with 860,390 metric tonnes of $\mathrm{NO}_{2}, 218,700$ metric tonnes of $\mathrm{SO}_{2}$ and 23,964 metric tonnes of $\mathrm{PM}_{10}$, mainly from the use of petroleum and the use of coal for power generation (DOE 2017). Furthermore, for the year 2018, CO pollutant emissions of 2,210,634 metric tonnes, as well as 889,890 metric tonnes of $\mathrm{NO}_{2}, 257,457$ metric tonnes of $\mathrm{SO}_{2}$, and 26,789 metric tonnes of $\mathrm{PM}$ were recorded (DOE 2018). The pollutants were made up of $\mathrm{PM}_{10}$, power plants representing $36 \%$ of the total, while industrial activities (33\%), motor vehicle exhaust (16\%) and other sources (15\%) such as residential, commercial, non-energy, and agricultural uses represented the rest (DOE 2017). CO emissions from motor vehicles still dominated the CO emissions in Malaysia with $95.6 \%$ for 2018 (DOE 2018).

The Malaysian ambient air quality guidelines (RMAQG) were developed by the DOE in 1989, and stipulate the limits of pollutants, including $\mathrm{PM}_{10}, \mathrm{CO}, \mathrm{NO}_{2}$, $\mathrm{SO}_{2}$ and $\mathrm{O}_{3}$, that negatively affect the general health of the population. The New Malaysian Ambient Air Quality Standards (NMAAQS) were established in 2015 with improved limits for air pollutants, following three tier periods that were finally implemented in 2020 (DOE 2020). $\mathrm{PM}_{10}$ is the major air pollutant in most urban and suburban areas in Southeast Asia (Afroz et al. 2003; Abas et al. 2004b; Azmi et al. 2010; Jamalani et al. 2016).

Exposure to high $\mathrm{PM}_{10}$ levels and toxic gases can lead to an elevated risk of respiratory diseases, which increases the risks of heart and lung diseases (Botkin and Keller 2007). Exposure to high concentrations of pollutants in the air contributes to $7.6 \%$ of deaths out of all health problems worldwide (WHO 2016). Air pollution was identified as the fourth leading risk factor for death and disability worldwide with 6.7 million deaths associated with air pollution in 2019, and India and China continuously recorded the highest burdens of disease. Also, new research on the impacts of exposure to air pollution on newborn babies showed nearly 500,000 infants died in the first month after birth due to exposure to ambient air pollution, specifically in sub-Saharan Africa and Asia regions, in 2019 (HEI 2020).

Respiratory-related illnesses were the leading cause of death in Malaysia in 2011, at 10.35\% (Ministry of Health 2012). An increase in $\mathrm{PM}_{10}$ concentrations of $10 \mu \mathrm{g} / \mathrm{m}^{3}$ could increase the mortality rate by $0.27 \%$ per day in Asia (HEI International Scientific Oversight Committee 2010). The middle-aged, young children and the elderly are also vulnerable to the effects of $\mathrm{PM}_{10}$ (Liu et al. 2020), which can also cause premature death (Wang et al. 2020) and elevate the risk of deaths due to asthma (Zhang et al. 2020). The correlation between air pollution in major cities and the risk of exposure can affect the population's economy through increased costs for treatment and accessibility to quality healthcare.

Thus, the objective of this study is to examine the spatial relationship between the $\mathrm{PM}_{10}$ concentrations and the health risk posed to the population in the Klang Valley. Several spatial analyses from the Geographical Information System (GIS) include the inverse distance weighted (IDW) technique that was used to map the spatial distribution of $\mathrm{PM}_{10}$ concentrations in the Klang Valley for 10 years from 2000 to 2009. The years 2000 to 2009 were used as the analysis time period as the highest 24-h concentration of $\mathrm{PM}_{10}$ was recorded in 2005 at all stations, namely Klang, Petaling Jaya, Kajang, Shah Alam and Cheras. The highest 24-h concentration was $590 \mu \mathrm{g} / \mathrm{m}^{3}$ recorded at Klang station followed by the Shah Alam station which recorded $587 \mu \mathrm{g} / \mathrm{m}^{3}$ in August 2005 due to the impact from a transboundary haze episode which occurred in Indonesia and point and mobile sources such as industry and motor vehicles. For health risk analysis, data from 2000 to 2009 were used due to the constraints of population data obtained from The Census of Population and Housing Malaysia. The spatial statistical technique of Global Moran's I Spatial Autocorrelation was used to assess the statistical significance of the locations of the clusters of the $\mathrm{PM}_{10}$ concentrations. The optimized hotspot analysis can identify clustering of high and low areas of $\mathrm{PM}_{10}$ concentrations. Lastly, the population-weighted exposure level (PWEL) technique and the AirQ + model spatially assess the relationship between the air pollution levels and the risk of exposure to the population.

\section{Materials and methods Study area: the Klang Valley}

The Klang Valley, located on the southwest coast of Peninsular Malaysia, is an upcoming developing urban area. The Klang Valley comprises $2911.5 \mathrm{~km}^{2}$ across several districts in Selangor, namely Rawang, Gombak, Selayang, Ampang, Petaling Jaya, Subang Jaya, Shah Alam, Klang, Serdang, Kajang, Puchong, Cyberjaya, Sepang and the Federal Territory of Kuala Lumpur (Rahman et al. 2015a, b) (Fig. 1). There are four main Administrative Districts or Local Authority areas in the Klang Valley, namely Klang, Petaling, Hulu Langat and the Federal Territory of Kuala Lumpur (FTKL). The largest district administrative council is the Klang administrative council (Table 1).

The land-use categories in the Klang Valley are settlement (dwellings and municipalities), cropland, forest 


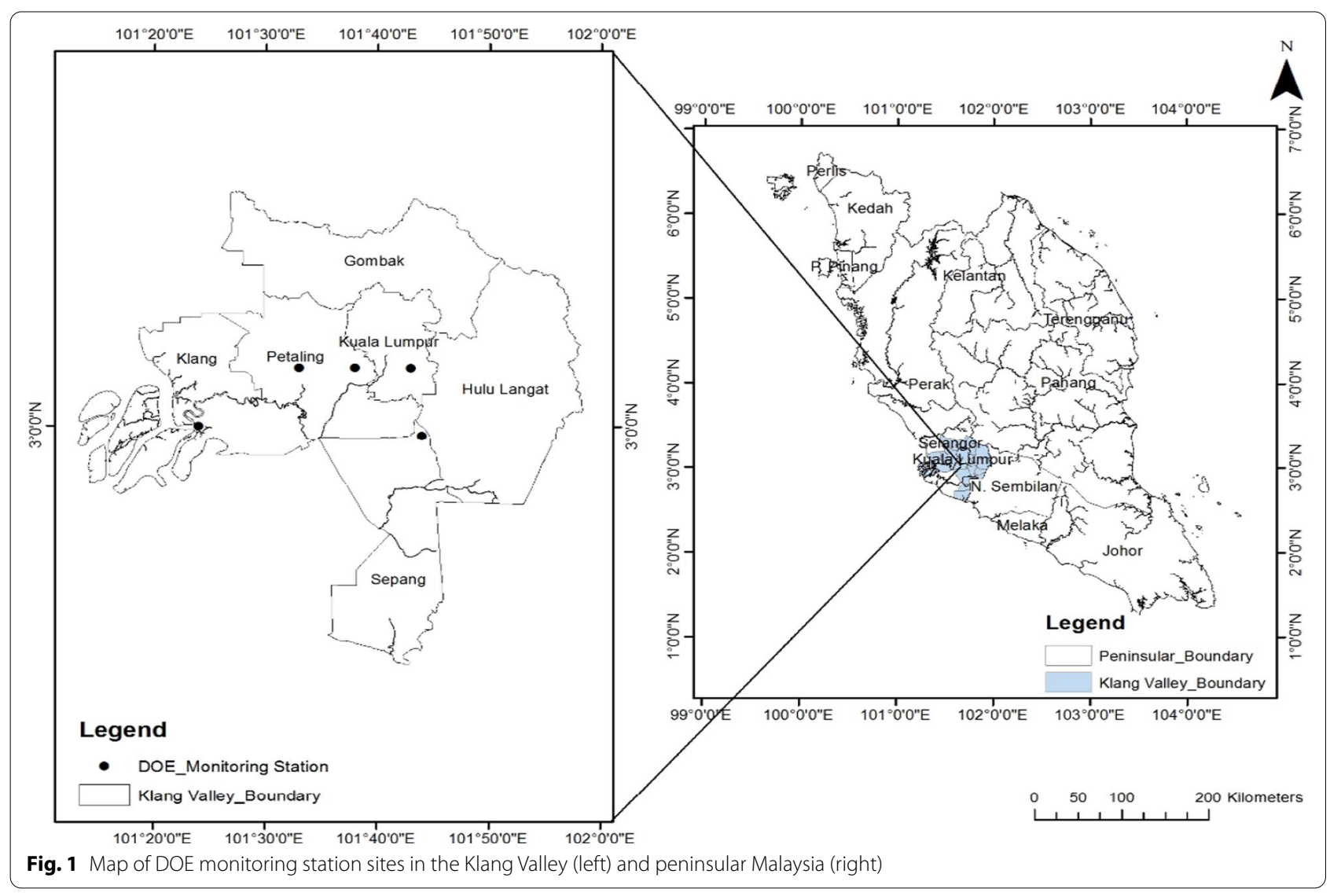

Table 1 Districts and area (ha) in the Klang Valley

\begin{tabular}{lc}
\hline District & Area (ha) \\
\hline Klang & $23,004.60$ \\
Petaling & 9488.77 \\
Hulu Langat & 5686.04 \\
FTKL & 243.00 \\
\hline
\end{tabular}

Source Selangor State Structure Plan 2002

land, grassland, peat swamp, mangrove, wetland, and other land uses. Districts with the largest settlement areas include Klang, Shah Alam, Petaling Jaya, Kajang and Cheras, an area totalling 1,489.76 ha. In the Klang district, agricultural cropland covers 957.05 ha with forest land consisting of an area of 741.62 ha (Selangor Department of Agriculture 2011).

\section{Data source}

Measurements of daily concentrations of $\mathrm{PM}_{10}$ were made available by the Air Quality Division, Department of Environment Malaysia (DOE) for the 10 years between 2000 and 2009. Five air quality stations representing different land uses were used: Klang (urban), Petaling Jaya (industrial), Kajang (residential), Shah Alam (urban), and Cheras (urban). However, data collection for the Cheras station only commenced in 2004. To ensure the reliability of the measurement process, Alam Sekitar Sdn Bhd (ASMA), a private company mandated by the DOE, conducts continuous monitoring and calibration of the equipment. Daily by hourly $\mathrm{PM}_{10}$ concentrations were recorded using a $\beta$-ray attenuation mass monitor BAM-1020 (Shaadan et al. 2015). In addition to the raw data, additional secondary data from DOE Annual Reports and the Annual Environmental Quality Report supplemented the data. Additional data from several DOE annual reports were intended only to support the problem statement, especially air pollutant emissions from various sources, and were not used in the data analysis process. The distribution trend of $\mathrm{PM}_{10}$ annual concentrations in the Klang Valley showed that Klang station recorded the highest annual average concentration of $590 \mu \mathrm{g} / \mathrm{m}^{3}$ and Shah Alam recorded $587 \mu \mathrm{g} / \mathrm{m}^{3}$ in August 2005. Cheras station also recorded its maximum annual $\mathrm{PM}_{10}$ concentration in August 2005, when it reached $465 \mu \mathrm{g} / \mathrm{m}^{3}$. 


\section{Population distribution data}

The Census of Population and Housing Malaysia for 2000 and 2010 provided the input data for the population. For this study, the annual population data for 2001 to 2009 were extrapolated, since the census is only available every 10 years (Department of Statistics Malaysia 2000, 2010).

\section{Spatial analysis}

Interpolation techniques used to analyse spatial data utilized the Geographic Information System (GIS) with ArcMap version 10.3 in ArcGIS. The interpolation techniques comprised a set of procedures to predict new values in areas with limited sampling points by considering that adjacent or nearby sampling points had interdependent relationships. The inverse distance weighted (IDW) technique predicts the influence of the known sample point after weighting by the inverse distance between two points (De Mesnard 2013; Yu et al. 2017).

The surface characteristics of the interpolation data can be controlled and determined by limiting the observed sampling points or inputs used. The limited number of input points is very important in improving the flow of the forecasting process. It was found that input points located far from the cell location had very weak and inaccurate prediction analysis, resulting in less significant spatial relationships for each point. To avoid this issue, we directly specified the number of input points being used or the radius of the area, which represented the distance limit of the area with the input points used in the IDW interpolation technique. The IDW was formulated as:

$$
z(x)=\frac{\sum_{i=1}^{n} w_{i}(x) z_{i}}{\sum_{j=1}^{n} w_{j}(x)}, \quad w_{i}(x)=\frac{1}{d\left(x, x_{i}\right)^{p}},
$$

where $Z(x)=$ predicted value at the interpolated point; $x_{i}=$ value of the $i$ th known sample point, i.e. the annual average concentration of $\mathrm{PM}_{10}$ at five air quality stations; $d=$ distance between the known sample point and the prediction point; $n=$ total number of the known sample points and refers to the five air quality stations, namely Klang, Petaling Jaya, Kajang, Shah Alam and Cheras; $w_{i}$ $=$ weight assigned to $i$ th known sample point and $p=$ weighting power-commonly this value is considered to be 2 .

In this study, the five DOE air quality stations represented the Klang Valley area. In the IDW space interpolation process, default values interpolate the spatial variation of $\mathrm{PM}_{10}$ concentration. In this regard, the nearest points were projected to record higher or almost similar concentrations and vice versa.

\section{Spatial statistical analysis}

\section{Global Moran's I spatial autocorrelation (Moran's I)}

The spatial autocorrelation method measures the relationship among variables across a georeferenced space (Getis 2008). Two types of spatial autocorrelation were used in this study, namely Global Moran's $I$ statistic and Getis-Ord general G. Global Moran's I tests for spatial correlation or clustering (Ya'acob and Mar Iman 2018). The Moran's $I$ test indicates positive spatial autocorrelation if $I>0$, negative spatial autocorrelation $(I<1)$ and no spatial autocorrelation if $I=0$ (Yang et al. 2020).

Spatial correlation is significant if both the $z$-score and $p$-value from the Moran's $I$ are significant at a $p$-value $<0.05$. Furthermore, a positive $z$-score indicates a clustering of $\mathrm{PM}_{10}$ concentrations among the five stations. A negative $z$-score value indicates the presence of an outlier, while a $z$-score of 1 represents an insignificant relationship where the $\mathrm{PM}_{10}$ concentrations varied across the stations. In this study, the null hypothesis $\left(\mathrm{H}_{0}\right)$ refers to the insignificant relationship between the distribution of $\mathrm{PM}_{10}$ concentrations and the locations of air quality stations.

\section{Optimized hot spot analysis}

Hot spot analysis measures the high-value hotspots, lowvalue cold spots and identifies spatial clusters that have statistical significance (Kang et al. 2018; Douglas et al. 2019). The optimized hot spot analysis (OHSA) is a tool extension (Holm 2018) that implements the Getis-Ord $\mathrm{Gi}^{*}$ method and analyses all spots in administrative border or grid cell units to obtain the optimal results (Kang et al. 2018). In this study, the study area was gridded into a $1 \mathrm{~km} \times 1 \mathrm{~km}$ lattice and the concentrations of $\mathrm{PM}_{10}$ were calculated according to the pixel of each grid. The Getis-Ord Gi* statistics formula for the hot spot analysis is shown below:

$$
\begin{gathered}
G_{i}^{*}=\frac{\sum_{j=1}^{n} \mathcal{W}_{i j} \mathcal{X}_{j}-\bar{X} \sum_{j=1}^{n}=1 \mathcal{W}_{i j}}{\frac{S \sqrt{\left[n \sum_{j=1}^{n} \mathcal{W}_{i j}^{2}-\left(\sum_{j=1}^{n} \mathcal{W}_{i j}\right)^{2}\right]}}{n-1}}, \\
\bar{X}=\frac{\sum_{j=1}^{n} \mathcal{X}_{j}}{n}, s=\frac{\sqrt{\sum_{j=1}^{n} \mathcal{X}_{j}^{2}}}{n}-(\bar{X})^{2},
\end{gathered}
$$

where $n=$ total number of features; $w_{i j}=$ value of spatial weight between $i$ and $j$ and $x_{j}=$ attribute value for feature $j$. The $\mathrm{Gi}^{*} z$-score value obtained represents statistically significant hot spots and cold spots. $\mathrm{Gi}^{*} z$-score values for cold spots were recorded as $-21.28<z$-score $<-12.0$ $1,-12.01<\mathrm{z}$-score $<-6.30$, and $-6.20<z$-score $<-2.21$ for cold spots with 99\%, 95\% and 90\% confidence 
levels respectively, while $-2.21<\mathrm{z}$-score $<1.00$ are not significant. For hot spots it showed a $\mathrm{Gi}^{*} z$-score value of $1.00<z$-score $<3.97$ for a significant value of $90 \%$ confidence, $3.97<z$-score $<7.61$ for $95 \%$ confidence, and $7.61<z$-score $<12.35$ for significant value at $99 \%$ confidence.

\section{Population-weighted exposure level (PWEL)}

The population-weighted exposure level (PWEL) technique can indicate the exposure of the population to suspended particulate matter, based on the population distribution data and particulate matter $\left(\mathrm{PM}_{10}\right)$ concentrations in a given area (Liu et al. 2017). The PWEL calculation is performed using the following equation (Ivy et al. 2008):

$$
\text { PWEL }=\frac{\sum(\mathrm{Pi} \times \mathrm{Ci})}{\sum \mathrm{Pi}},
$$

where $P_{i}=$ population in area $i ; C_{i}=\mathrm{PM}_{10}$ concentration in area $i$.

In this study, the concentration of $\mathrm{PM}_{10}$ is potentially harmful if the level exceeds the criteria limit set by the local authorities for the vulnerable population in the Klang Valley. The PWEL value obtained was compared with the standard limit stated in the New Malaysian Ambient Air Quality Standard (NMMAQS) and World Health Organization (WHO) guidelines of $40 \mu \mathrm{g} / \mathrm{m}^{3}$ and $20 \mu \mathrm{g} / \mathrm{m}^{3}$, respectively. However, this study only focused on the four districts in Selangor: Klang, Hulu Langat and Petaling as well as the Kuala Lumpur. Data from Gombak and Sepang were not included in this study due to the limited availability of data.

\section{The AirQ+ model}

The AirQ+ model was developed by the WHO Regional Office for Europe to calculate the health risks to individuals due to air pollution. The main purpose of the AirQ+ model is to provide useful information concerning the impacts of air pollutants in order to minimize the health effects based on human exposure, and further applying practical and effective solutions by stakeholders for the community (Khaniabadi et al. 2018). The calculation process in the AirQ+model involves several important items, namely the risk duration period (long- and short-term), the type of pollutants for analysis $\left[\mathrm{PM}_{10}\right.$, $\mathrm{PM}_{2.5}, \mathrm{NO}_{2}, \mathrm{O}_{3}$ and black carbon (BC)] and the type of individual health risk (mortality and morbidity, particularly serious acute respiratory problems such as bronchitis cases among adults and children).

The purpose of the application of the AirQ+ model version 2.0 in this study was to estimate the risk of respiratory-related diseases such as chronic bronchitis among the adult age group due to the long-term impact of $\mathrm{PM}_{10}$ concentrations according to district in the Klang Valley. The data used in the analysis process of the AirQ+ model were the annual average concentration of $\mathrm{PM}_{10}$ by district (Klang, Petaling, Hulu Langat and Kuala Lumpur), the total cumulative population, and the population density by each district. The process of analysing the estimated risk of chronic bronchitis among adults using the AirQ+ model began with the first step, which was entering the data in "Analysis Properties" which consisted of annual averages of $\mathrm{PM}_{10}$ concentration in each district by year, total population and population density by district. The second step was the "Impact Assessment", which was to calculate the estimated risk of chronic bronchitis among adults for each district and each year of the study. The equation of the AirQ+ model used in the analysis is shown in Eq. 5 below:

$$
\mathrm{AP}=((\mathrm{RR}-1) \cdot \mathrm{P}) /(\mathrm{RR} \cdot \mathrm{P}),
$$

where $\mathrm{AP}=$ an attributable proportion of chronic bronchitis in adults; $R R=$ the relative risk for a particular health outcome determined by exposure to $\mathrm{PM}_{10}$; and $\mathrm{P}=$ the fraction of the population exposed to $\mathrm{PM}_{10}$.

The outcome from the AirQ+ model analysis was the estimated proportion of the adult population at risk of chronic bronchitis for each district, shown in spatial form, for every year from 2000 to 2009 in the Klang Valley.

\section{Results and discussion}

\section{Spatial variations of $\mathrm{PM}_{10}$ concentrations}

The spatial variation of $\mathrm{PM}_{10}$ concentrations in the Klang Valley showed fluctuating changes from 2000 to 2009. The highest average annual $\mathrm{PM}_{10}$ concentration was $100 \mu \mathrm{g} / \mathrm{m}^{3}$ in the Klang Valley. In 2000, the Klang and Kajang stations recorded elevated $\mathrm{PM}_{10}$ concentrations of between 80 and $100 \mu \mathrm{g} / \mathrm{m}^{3}$ and the Petaling Jaya station also displayed a similar but smaller distribution range (Fig. 2). Shah Alam also showed high average $\mathrm{PM}_{10}$ concentrations of between 60 and $80 \mu \mathrm{g} / \mathrm{m}^{3}$. A similar pattern of high concentrations at almost the same locations occurred in 2001 (Fig. 2). Klang and Petaling Jaya stations again recorded high $\mathrm{PM}_{10}$ concentrations of between 80 and $100 \mu \mathrm{g} / \mathrm{m}^{3}$. Similar patterns were displayed in 2002 (Fig. 2) and 2003 (Fig. 2), with slight differences in the $\mathrm{PM}_{10}$ distributions. The downward trend continued at Kajang and in 2002 it recorded $\mathrm{PM}_{10}$ concentrations of between 40 and $60 \mu \mathrm{g} / \mathrm{m}^{3}$.

The declining trend of $\mathrm{PM}_{10}$ concentrations continued in 2005 at Kajang and Cheras, both of which recorded average values of below $40 \mu \mathrm{g} / \mathrm{m}^{3}$ (Fig. 2). A similar decline was found at Shah Alam and Petaling Jaya where $\mathrm{PM}_{10}$ distributions of between 40 and $60 \mu \mathrm{g} / \mathrm{m}^{3}$ were 


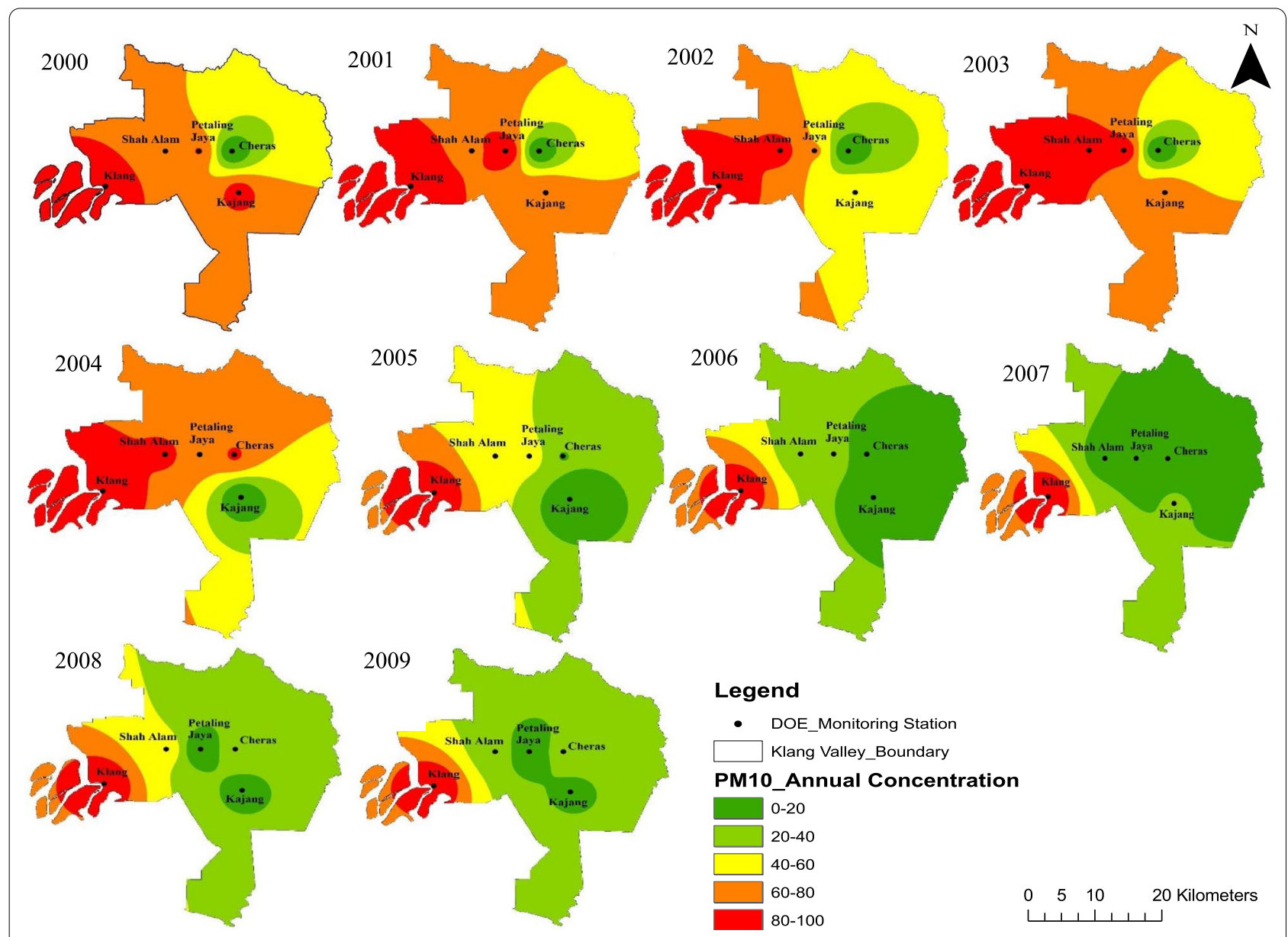

Fig. 2 Spatial variations of annual-averaged $\mathrm{PM}_{10}$ concentration $\left(\mu \mathrm{g} / \mathrm{m}^{3}\right)$ at five DOE monitoring stations in the Klang Valley; Klang, Shah Alam, Petaling Jaya, Cheras and Kajang station from 2000 to 2009

recorded. Klang still showed the highest $\mathrm{PM}_{10}$ range of between 60 and $100 \mu \mathrm{g} / \mathrm{m}^{3}$ in 2005 and 2006, followed by the Shah Alam, Petaling Jaya, Cheras and Kajang stations where values of between 20 and $40 \mu \mathrm{g} / \mathrm{m}^{3}$ were recorded (Fig. 2).

In short, high average $\mathrm{PM}_{10}$ concentrations occurred from 2000 to 2003 in the Klang Valley, which subsequently decreased from 2004 to 2009. Maximum $\mathrm{PM}_{10}$ concentrations consistently occurred in Klang, ranging from 80 to $100 \mu \mathrm{g} / \mathrm{m}^{3}$ and 60 to $80 \mu \mathrm{g} / \mathrm{m}^{3}$ from 2000 to 2009. The other stations displayed lower concentrations of between 40 and $100 \mu \mathrm{g} / \mathrm{m}^{3}$ from 2000 to 2003, which then declined to below $60 \mu \mathrm{g} / \mathrm{m}^{3}$ from 2004 to 2009 .

\section{Clustering of $\mathrm{PM}_{10}$ concentrations}

The Moran's $I$ results measure the intensity of clustering based on the $z$-score value at a $p$-level of 0.05 . These results demonstrate the existence of spatial $\mathrm{PM}_{10}$
Table 2 Spatial patterns of $\mathrm{PM}_{10}$ concentrations in the Klang Valley from 2000 to 2009 based on the Moran's / analysis

\begin{tabular}{|c|c|c|c|c|}
\hline \multirow[t]{2}{*}{ Year } & \multicolumn{2}{|l|}{ Moran's I } & \multirow{2}{*}{$\begin{array}{l}\text { Relationship } \\
p \text {-value }\end{array}$} & \multirow[t]{2}{*}{ Pattern } \\
\hline & Index value & $z$-score & & \\
\hline 2000 & 0.49 & 41.31 & 0.00 & Cluster \\
\hline 2001 & 0.51 & 43.10 & 0.00 & Cluster \\
\hline 2002 & 0.60 & 50.91 & 0.00 & Cluster \\
\hline 2003 & 0.53 & 45.26 & 0.00 & Cluster \\
\hline 2004 & 0.32 & 27.24 & 0.00 & Cluster \\
\hline 2005 & 0.31 & 25.91 & 0.00 & Cluster \\
\hline 2006 & 0.29 & 24.15 & 0.00 & Cluster \\
\hline 2007 & 0.28 & 23.91 & 0.00 & Cluster \\
\hline 2008 & 0.30 & 25.24 & 0.00 & Cluster \\
\hline 2009 & 0.28 & 24.14 & 0.00 & Cluster \\
\hline
\end{tabular}


concentration clusters across the Klang Valley over the ten years studied (Table 2).

Positive and significant autocorrelations exist between stations from 2000 to 2003, as represented by high $z$-scores of 41.31, 43.10, 50.01 and 45.26, for those years, respectively. This indicates that there was a significant relationship between the concentrations of $\mathrm{PM}_{10}$ at all stations. Subsequently, in later years (2004 to 2009), the positive $z$-score values were lower. There still existed a strong autocorrelation of the $\mathrm{PM}_{10}$ spatial concentration located near each other, indicating the formation of clusters (Table 2). The $p$-value of 0.00 also confirms that there were significant relationships and the presence of $\mathrm{PM}_{10}$ concentration clustering in the Klang Valley.

\section{Hot spot areas of the $\mathrm{PM}_{10}$ concentrations}

Klang was the highest zone of $\mathrm{PM}_{10}$ clustering with 99\% confidence. Besides Klang, Shah Alam was also a highrisk area for $\mathrm{PM}_{10}$ from 2000 to 2009, as it recorded high concentrations of $\mathrm{PM}_{10}$ between 2001 and 2005 with hot spots distribution of statistically confident levels of 95 to 99\%. Towards the end of 2009, Shah Alam displayed a statistically high level of $99 \%$ with cold spots in 2007 and 2008 (Fig. 3).

The hot spots trend in the Petaling Jaya area was variable, where the district recorded high hot spot distributions in 2000, 2001 and 2003 at 99\% confidence, but this declined to only 90\% in 2005. In 2008 and 2009, Petaling Jaya recorded cold spot distributions of statistical significance at 95 to $99 \%$, which indicated it was an area with lower health risks to the local population. Kajang was a hot spot area in the early years from 2000 to 2001 but became a statistically significant (95 to $99 \%$ ) cold spot area from 2004 to 2009. This decreasing trend in the $\mathrm{PM}_{10}$ concentrations in Kajang implies improving air quality in the district (Fig. 3).

In short, Klang is the district with the highest $\mathrm{PM}_{10}$ concentrations that pose a significant health risk to the local community. Inhabitants are more susceptible to various chronic diseases, such as respiratory tract

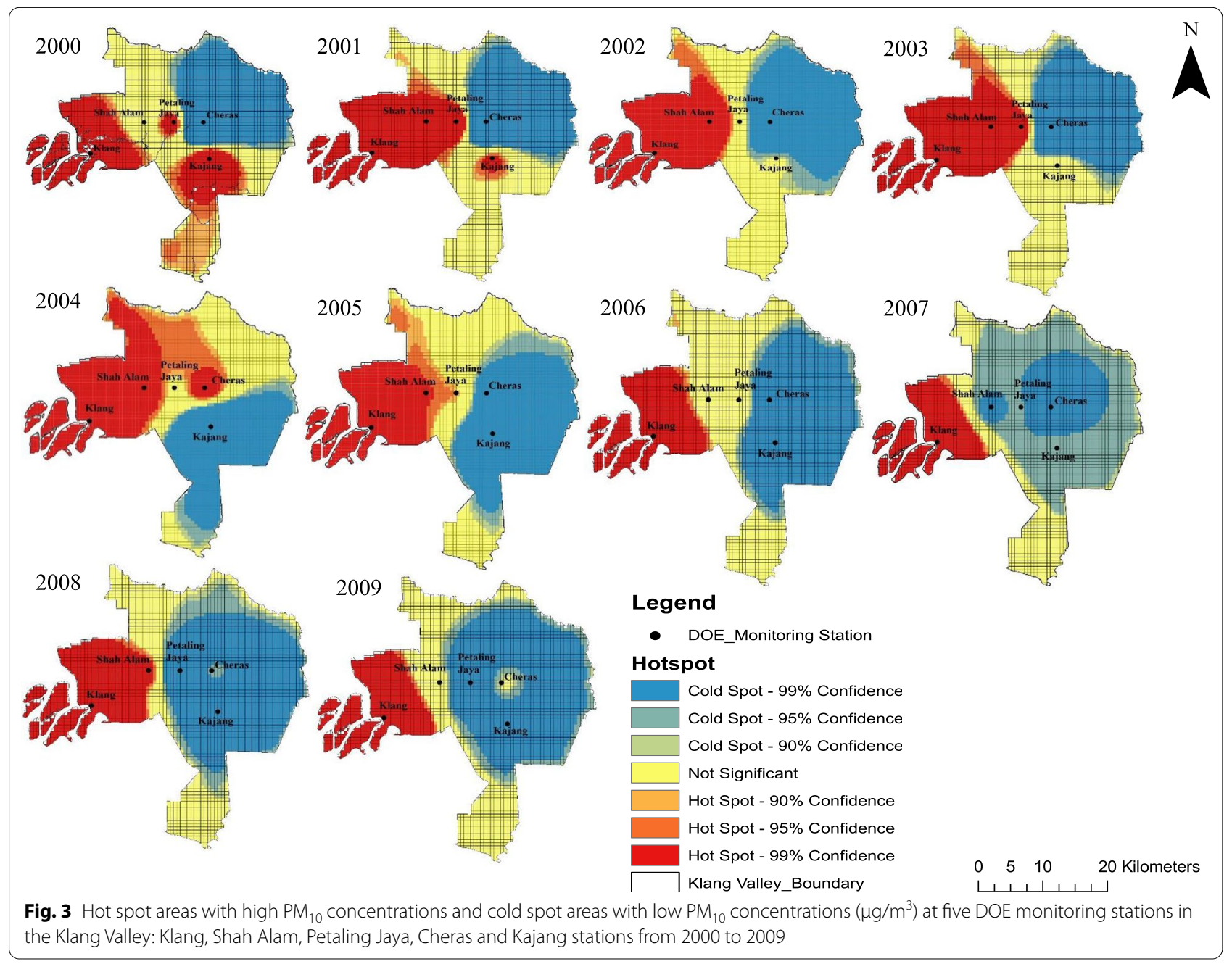


diseases, particularly the elderly and children, due to the consistent exposure to high $\mathrm{PM}_{10}$ concentrations over a long period.

\section{Population exposure to $\mathrm{PM}_{10}$ concentrations}

According to records from the 2010 Malaysian Population and Housing Census, Department of Statistics Malaysia, the estimated cumulative total population in the Klang Valley between 2000 and 2009 was 54,619,961 across the Gombak, Hulu Langat, Klang, Petaling, and Sepang districts in Selangor, as well as the Kuala Lumpur. The highest population was concentrated in the Petaling district with $27.28 \%$ (14,905,076 people), followed by Kuala Lumpur with $26.03 \%$ or $14,220,633$ people. Sepang had the lowest population, with $1,536,905$ people, encompassing $2.81 \%$ of the total population in the Klang Valley (Fig. 4).

In terms of population density, the Kuala Lumpur recorded the highest density with $58,281.28$ people $/ \mathrm{km}^{2}$ compared to $29,990.09$ people $/ \mathrm{km}^{2}$ in Petaling. Other districts recorded population densities of 12,544.49 people $/ \mathrm{km}^{2}$ (Klang), 12,058.00 people $/ \mathrm{km}^{2}$ (Hulu Langat),
$9,887.05$ people $/ \mathrm{km}^{2}$ (Gombak) and 2600.52 people $/ \mathrm{km}^{2}$ (Sepang) from 2000 to 2009 . The high population density in Kuala Lumpur is due to factors such as higher employment opportunities, better access to education (especially tertiary education), and the rapid development of the economic and service sectors (Fig. 4).

\section{Population-weighted exposure level (PWEL) for the Klang Valley (2000-2009)}

The risk to the population in the Klang Valley from the mean annual $\mathrm{PM}_{10}$ exposure was small, as the PWEL values of $28 \mu \mathrm{g} / \mathrm{m}^{3}$ from 2000 to 2009 were within the guidelines of the NMAAQS (2020) of $40 \mu \mathrm{g} / \mathrm{m}^{3}$. However, the PWEL values exceeded the WHO Air Quality Guideline (AQG) values of $20 \mu \mathrm{g} / \mathrm{m}^{3}$ (WHO 2005) (Fig. 5). The high population density area in Petaling was also at risk of respiratory health problems as a PWEL value of $15 \mu \mathrm{g} / \mathrm{m}^{3}$ existed from 2000 to 2009 . The densely populated area in the Kuala Lumpur had a higher health risk as it recorded a PWEL value of above $15 \mu \mathrm{g} / \mathrm{m}^{3}$ from 2004 to 2009 (Fig. 5).

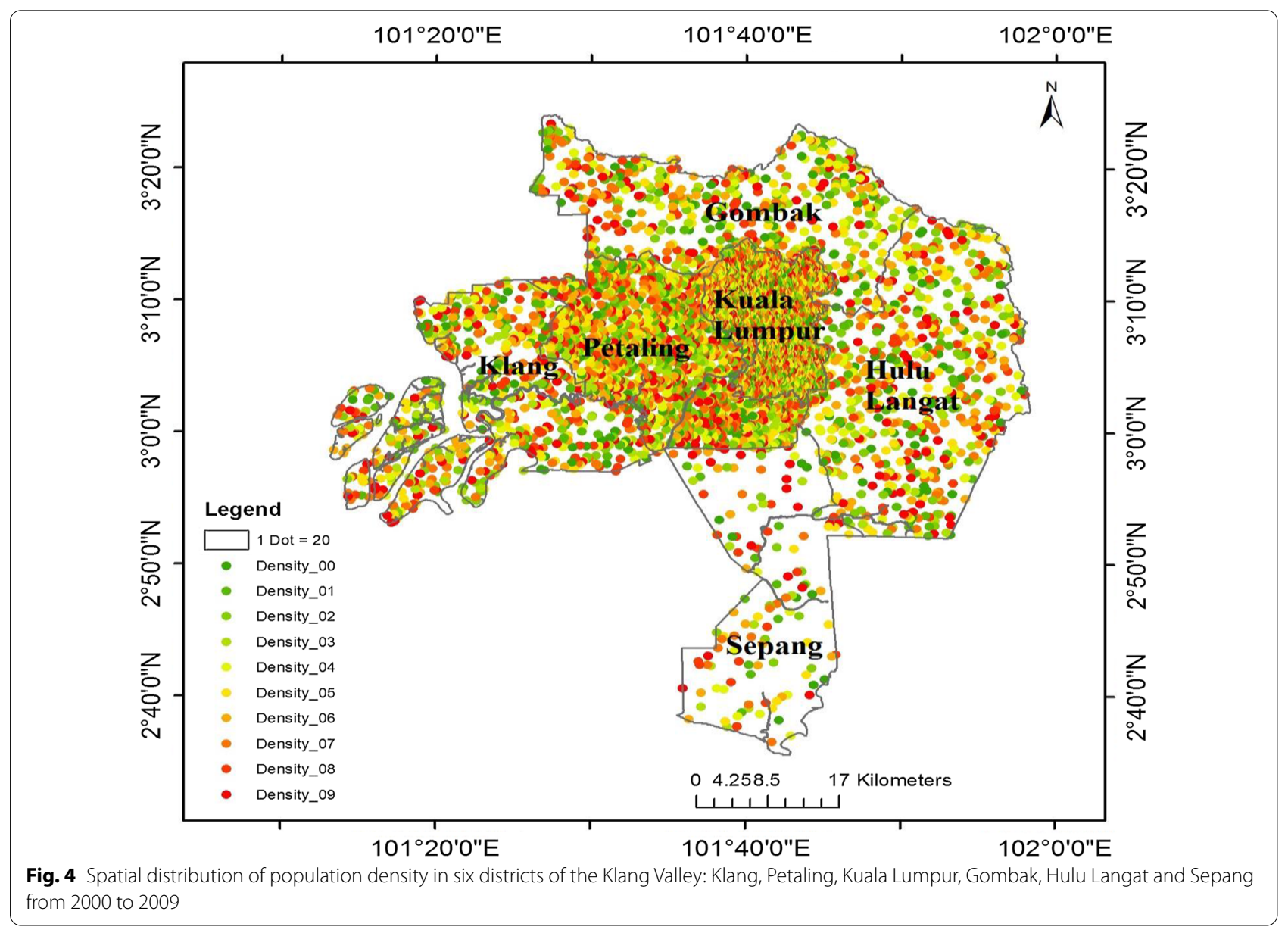




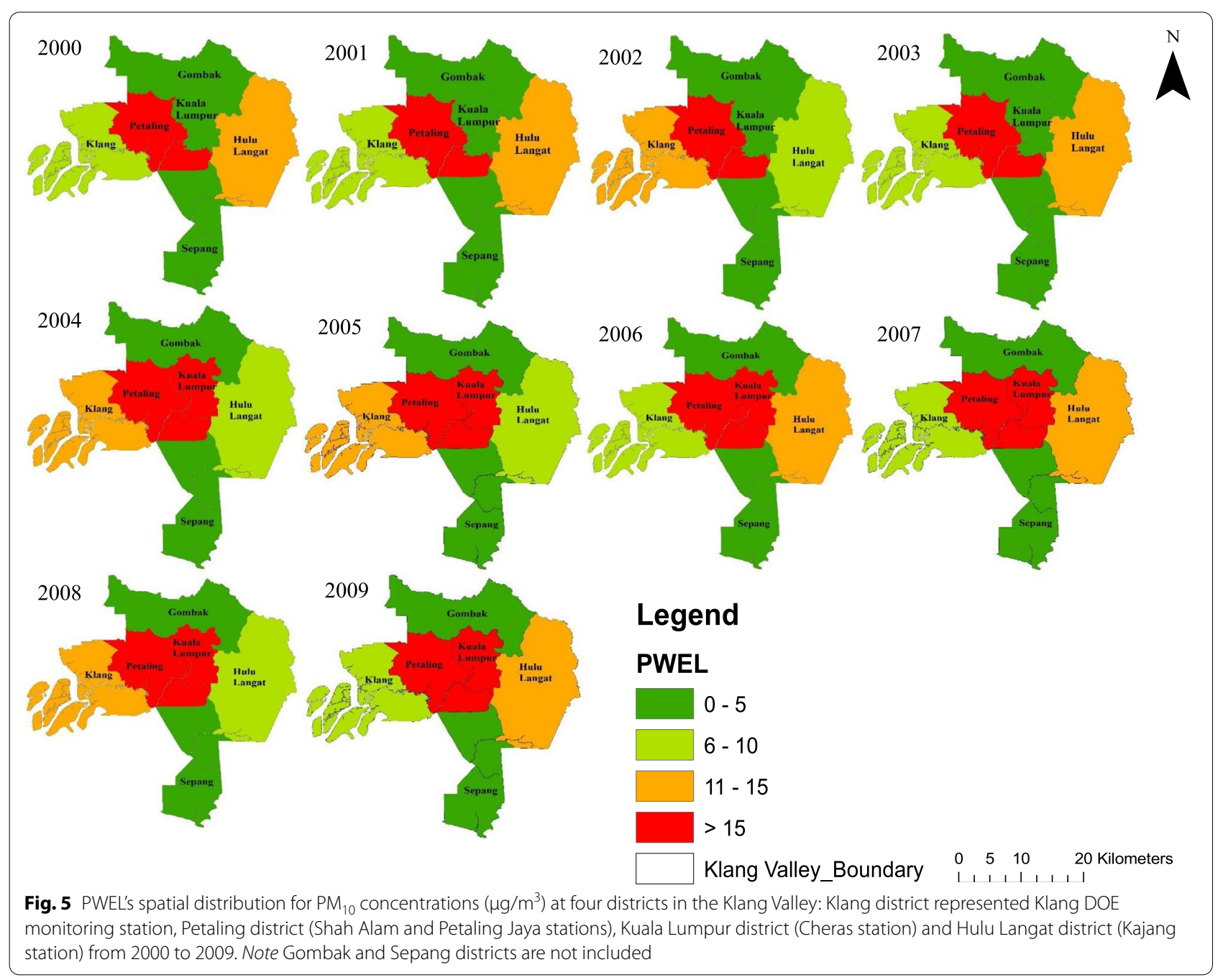

The Klang district, on the other hand, recorded varied PWEL values from 2000 to 2009 of between 11 and $15 \mu \mathrm{g} / \mathrm{m}^{3}$ in 2002, 2004, 2005 and 2008 compared to lower values of 6 to $10 \mu \mathrm{g} / \mathrm{m}^{3}$ in other years. This situation occurred due to the high $\mathrm{PM}_{10}$ concentrations in Klang of between 80 and $100 \mu \mathrm{g} / \mathrm{m}^{3}$ in 2002. However, the PWEL in Hulu Langat of between 6 and $10 \mu \mathrm{g} / \mathrm{m}^{3}$ in 2002, 2004, 2005 and 2008 showed that the $\mathrm{PM}_{10}$ exposure in Hulu Langat was minimal due to the low $\mathrm{PM}_{10}$ concentrations and lower population density compared to other districts in the Klang Valley (Fig. 5).

The results of the analysis of the AirQ+ model found that the overall relative risk (RR) was greater than 1 , which shows that the rate of exposure for the population of the Klang Valley to $\mathrm{PM}_{10}$ concentrations was relatively high in all districts from 2000 to 2009 (Fig. 6, Table 3). This situation is evidenced by the spatial distribution of the estimated population exposed to the highest $\mathrm{PM}_{10}$ concentrations recorded in Klang. This population showed an increasing trend each year from 300,000 to 600,000 people $(542,952$ people in 2000) with further increases to an estimated 900,000 people from 2002 to 2009 , with 790,303 people and 804,240 people, recorded in Klang in those years, respectively.

During the 10 years of the study, the Klang population was very vulnerable to high $\mathrm{PM}_{10}$, especially in 2009 and 2008 with 804,240 people at risk (RR: 1.85) and 803,062 people at risk (RR: 2.14), respectively. The estimated trend of the proportion of the population of Klang being exposed to high $\mathrm{PM}_{10}$ concentrations was high due to the PWEL value obtained being significantly high in 2008-between 11 and $15 \mu \mathrm{g} / \mathrm{m}^{3}$. In addition, the cumulative population of Klang was high compared to other districts, increasing from $1,254,800$ people in 2000 to 1,750,631 people in 2009.

Besides Klang, Kuala Lumpur was also identified as a high-risk district with a vulnerable population due to long-term exposure to $\mathrm{PM}_{10}$ concentrations. Kuala 


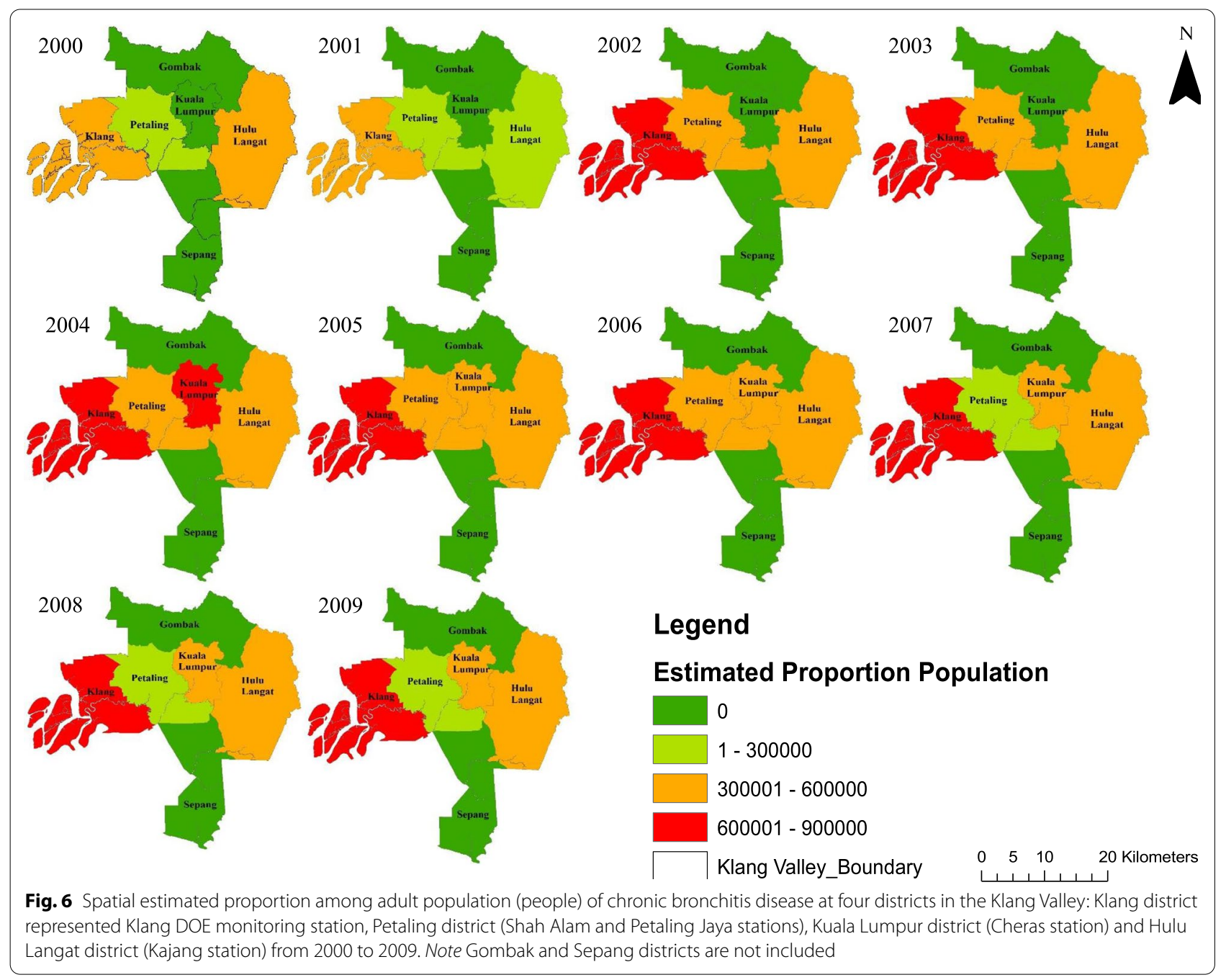

Table 3 Estimated proportion among adult population (people) and relative risk (RR) of chronic bronchitis disease at four districts in the Klang Valley: Klang, Petaling, Hulu Langat and Kuala Lumpur district from 2000 to 2009

\begin{tabular}{|c|c|c|c|c|c|c|c|c|}
\hline \multirow[t]{2}{*}{ Year } & \multicolumn{2}{|l|}{ Klang } & \multicolumn{2}{|l|}{ Petaling } & \multicolumn{2}{|c|}{ Hulu Langat } & \multicolumn{2}{|l|}{ Kuala Lumpur } \\
\hline & $\begin{array}{l}\text { Relative } \\
\text { risk (RR) }\end{array}$ & $\begin{array}{l}\text { Estimated } \\
\text { proportion } \\
\text { (people) }\end{array}$ & $\begin{array}{l}\text { Relative } \\
\text { risk (RR) }\end{array}$ & $\begin{array}{l}\text { Estimated } \\
\text { proportion } \\
\text { (people) }\end{array}$ & $\begin{array}{l}\text { Relative } \\
\text { risk (RR) }\end{array}$ & $\begin{array}{l}\text { Estimated } \\
\text { proportion } \\
\text { (people) }\end{array}$ & Relative risk (RR) & $\begin{array}{l}\text { Estimated } \\
\text { proportion } \\
\text { (people) }\end{array}$ \\
\hline 2000 & 1.76 & 542,952 & 1.46 & 214,122 & 1.62 & 349,797 & No data & \\
\hline 2001 & 1.65 & 511,203 & 1.53 & 243,030 & 1.46 & 295,531 & & \\
\hline 2002 & 2.41 & 790,303 & 1.90 & 337,623 & 1.53 & 333,760 & & \\
\hline 2003 & 1.89 & 659,691 & 1.77 & 316,701 & 1.53 & 341,133 & & \\
\hline 2004 & 2.02 & 734,899 & 1.87 & 348,135 & 1.49 & 337,571 & 1.91 & 668,359 \\
\hline 2005 & 2.14 & 803,062 & 1.83 & 346,828 & 1.57 & 371,061 & 1.67 & 573,595 \\
\hline 2006 & 1.87 & 727,109 & 1.66 & 311,778 & 1.58 & 384,950 & 1.57 & 530,614 \\
\hline 2007 & 1.60 & 611,124 & 1.47 & 256,651 & 1.48 & 351,203 & 1.46 & 466,857 \\
\hline 2008 & 1.84 & 767,772 & 1.52 & 280,649 & 1.48 & 355,412 & 1.54 & 531,104 \\
\hline 2009 & 1.85 & 804,240 & 1.54 & 292,797 & 1.55 & 397,695 & 1.58 & 571,814 \\
\hline
\end{tabular}


Lumpur recorded the highest population exposure rate of between 600,0001 to 900,000 with 668,359 people in 2004. As a result, the population exposure rate was significantly high with a RR value of 1.91 . This situation was due to the $\mathrm{PM}_{10}$ concentrations at Cheras station of between 60 and $80 \mu \mathrm{g} / \mathrm{m}^{3}$ in 2004 and the highest population density of $58,281.28$ people $/ \mathrm{km}^{2}$, leading to a PWEL value of $20 \mu \mathrm{g} / \mathrm{m}^{3}$ in 2009 . However, from 2005 to 2009 , there was a downward trend in the population's estimated exposure to $\mathrm{PM}_{10}$ in Kuala Lumpur, only recording 573,595 people in 2005 and decreasing to 571,814 people in 2009 with accounted exposures rates of between 300,001 and 600,000 people although the value of PWEL remained high (Fig. 6).

For the Petaling district, the results showed an estimated population exposure to $\mathrm{PM}_{10}$ concentrations from 2000 to 2009 of from 1 to 300,000 people in 2000 and 2001 with 214,122 and 243,030 people, respectively (Fig. 6). Then, the trend significantly increased between the rates of 300,001 and 600,000 people from 2002 to 2006 , from 337,623 people to 311,778 people and decreased back to ranging from 1 to 300,000 people for the years 2007 to 2009 with 256,651 people and 292,797 people. However, the value of PWEL in Petaling was the highest every year at 16 to $20 \mu \mathrm{g} / \mathrm{m}^{3}$, influenced by the high population density, reaching $29,990.09$ people $/ \mathrm{km}^{2}$, with an average $\mathrm{PM}_{10}$ concentration of between 60 and $100 \mu \mathrm{g} / \mathrm{m}^{3}$, especially in 2000 to 2004 . Also, the same situation occurred in Hulu Langat district, where the population's exposure to $\mathrm{PM}_{10}$ was estimated between 300,001 and 600,000 people each year from 349,797 people to 397,695 people, except for 2001, which recorded a range of 1 to 300,000 people $(349,797$ people). This situation is in line with the PWEL value recorded which was also uneven at between 6 and $16 \mu \mathrm{g} / \mathrm{m}^{3}$ according to the year, although the population of Hulu Langat was among the highest from 915,700 people in 2000 to $1,126,295$ people in 2009 (Fig. 6).

The spatial distribution pattern of $\mathrm{PM}_{10}$ in the Klang Valley region (2000-2009) revealed that most of the areas in the Klang Valley were contaminated with annual $\mathrm{PM}_{10}$ levels exceeding the recommended DOE threshold of $50 \mu \mathrm{g} / \mathrm{m}^{3}$ and the WHOAQG level. These PWEL results revealed that the population in Klang Valley, particularly in the districts of Petaling and the Kuala Lumpur, was at risk from the exposure to the mean annual $\mathrm{PM}_{10}$ concentrations that exceeded the annual NMAAQS and the WHOAQG levels.

According to Jamalani et al. (2016), the Klang, Petaling Jaya, Kajang and Shah Alam stations have been found to be affected by $\mathrm{PM}_{10}$. Serious traffic congestion, especially during peak hours, inefficient public transport services, and the poor physical condition of the roads directly contribute to increased emissions of traffic (Awang et al. 2000) and significantly increase the exposure of the population to health risks in the Klang Valley. The PWEL values obtained indicated that Petaling Jaya and Shah Alam were the most at risk areas for $\mathrm{PM}_{10}$ pollution in 2000 and 2009. The increasing number of vehicles led to higher use of hydrocarbons like petrol. This contributed to the increase in emissions from vehicles, which was classified as the major cause of air quality deterioration in Malaysia (DOE 2015). The total number of new motor vehicles registered from 2010 to 2014 included private cars, motorcycles, goods vehicles, and buses. The annual trend in new vehicles showed a continuous increase of $3.71 \%$ per year from 2010 to 2014 in Kuala Lumpur. Consequently, the total $\mathrm{PM}_{10}$ emissions from all classes of motor vehicles in Kuala Lumpur estimated from the tail-pipe exhaust was $1,029,883 \mathrm{~kg}$, with newly registered private cars at $214,427 \mathrm{~kg}$, followed by emissions from motorcycles at $118,582 \mathrm{~kg}$ in 2014 . Private cars also contributed 14,605 kg of CO and $5726 \mathrm{~kg}$ of $\mathrm{NO}_{x}$ in 2014, compared with $9830 \mathrm{~kg}$ of $\mathrm{CO}$ and $3854 \mathrm{~kg}$ of $\mathrm{NO}_{x}$ in 2010 (Shafie and Mahmud 2020). The concentrations of all pollutants peaked in the hours between 7:00 a.m. and 9:00 a.m. and at 5:00 p.m., when people were going to work, taking their children to school and returning home from work (Azmi et al. 2010; Rahman et al. 2015b). Meanwhile, Klang station was located near main roads and industrial and residential areas and thus experienced a high density of vehicles which significantly contributed to high concentrations of air pollutants (Azid et al. 2015). However, the decreasing trend of $\mathrm{PM}_{10}$ concentrations, particularly after 2007, was due to reduced regional biomass burning activities, as well as meteorological variables. Meteorological variables such as humidity, temperature, wind speed and wind direction were also found to contribute to the concentrations and distribution of air pollution, these having a strong correlation with temperature and a weak correlation with precipitation and humidity (Tarmizi et al. 2014; Noor et al. 2015; Mohtar et al. 2018).

The El Niño/Southern Oscillation (ENSO) episodes during the southwest monsoon also exacerbated the $\mathrm{PM}_{10}$ concentrations, whereas dry weather conditions affected the intensity of combustion and haze events (Mohtar et al. 2018; Sentian et al. 2018). In the El Niño dry period in the years 2002, 2004, 2006 and 2009, the numbers of detected hot spots were 3 to 4 times higher than in non-El Niño years (Latif et al. 2018). There are also specific topographic conditions of the Klang Valley that can lead to the accumulation of pollution. It is located near the coastal area facing the straits of Malacca and is mainly dominated by localized wind circulation from land and sea breezes. 
Malaysia and other Southeast Asian countries have been experiencing periodic haze episodes for decades due to forest fires on Indonesia's Sumatra Island. The Department of Environment (DOE) also stated that forest fires in Sumatra and Kalimantan, Indonesia, caused haze across the border and affected the increase in API readings in all areas along the west coast of Peninsular Malaysia and west Sarawak (DOE 2016). A total of 10,173 active fire counts were detected during August 2004 and the $\mathrm{PM}_{10}$ daily concentrations measured exceeded the 24-h Recommended Malaysian Air Quality Guidelines of $150 \mu \mathrm{g} / \mathrm{m}^{3}$ in three separate periods from the 13th to the 30th August 2004 (Mahmud 2012). From 2000 to 2009, Petaling Jaya stations showed the highest values (PWEL) with readings of $15 \mu \mathrm{g} / \mathrm{m}^{3} \mathrm{com}$ pared to 2004 and 2008. Apart from the high population density $\left(29,990\right.$ people $\left./ \mathrm{km}^{2}\right)$ affecting the rise of $\mathrm{PM}_{10}$, strong haze events in those years, especially 2005 also influenced the rise. This area was a hot spot area in 2005 and the situation was declared an emergency by the government after air pollution there reached a dangerous level (defined as a value greater than 500 in the Air Pollution Index or API). Fine particulate matter released in the air during transboundary haze can have a severe impact on human health (Shao et al. 2016). Epidemiological evidence from acute and chronic exposure to PM in ambient air has been linked to a number of different health outcomes, ranging from modest transient changes in the respiratory tract and impaired pulmonary function, through increased risk of symptoms requiring emergency room or hospital treatment, to increased risk of death from cardiovascular and respiratory diseases or lung cancer (Hanafi et al. 2018). During a haze event, in urban atmospheres such as Kuala Lumpur pollutants are likely to comprise both those from biomass burning and vehicular emissions. According to Abas et al. (2004a), the molecular composition of organic compounds found in airborne particles revealed that the total suspended particulate (TSP) and organic carbon concentrations were higher than on a non-hazy day, where 24 to $36 \%$ of TSP was organic matter and around $2 \%$ was elemental carbon (soot). The high concentrations of $\mathrm{PM}_{10}$, mostly affected by $\mathrm{PM}_{2.5}$ and carbonaceous elements, were also the most dominant fraction in biomass burning aerosol (Rahman et al. 2015a; Fujii et al. 2016). $\mathrm{PM}_{10}$ produces a high concentration of $\mathrm{NO}_{3}$ anions due to bacterial nitrification and oxidation during biomass peat soil combustion, as well as heavy metals from peatland soil being converted to particulate matter, with heavy metal characteristics found in the ash suspended in the air (Abdullah et al. 2020). As such, contaminated particulate matter has a strong correlation with exposure to health risks in the Klang Valley.

Furthermore, most of the urbanization process was represented by the agglomeration of the population in the major metropolitan areas (Mira et al. 2017) and Malaysia has witnessed rapid urban population growth in the past 90 years (Masron et al. 2012). Malaysia's urban population has been growing faster than the rural population owing to huge economic opportunities in the urban centres along with the growth of industrial, commercial, financial, and administration activities, especially in the Kuala Lumpur conurbation areas (Hasan and Nair 2014). Urbanization has increased the impact of urban air pollution in the Klang Valley. Klang Valley is Malaysia's main economic region with rapid industrialization, urbanization and infrastructure development, which have noticeably caused the deterioration of air quality (Rahman et al. 2015b). According to Ling et al. (2014), the size of the pollution-prone land-use coverage has the potential to raise air pollution levels. Abdullah et al. (2012) found that the $\mathrm{PM}_{10}$ concentrations in Klang, which is an urban area, were higher than that of suburban and rural areas. This is due to the high population growth, especially in the urban centres and major cities, as a result of the rapid economic growth, which has created many job opportunities and infrastructure in the area. Shakor (2020) indicated that the central regions such as Kuala Lumpur, Putrajaya and Selangor were considerably more urbanized with the level of urbanization about 91.4 to $100 \%$. In the year 2010 Selangor received higher urban migration rate, which was $33.3 \%$, and the KL was recorded at 7.0\% (Abdul Rashid 2017). Urban green spaces (UGS) in the Klang Valley have increased by $318.02 \%$ in proportion to built-up areas (high-density built-up (HDB) and low density built-up (LDB) areas) from 1989 to 2014. The percentages of UGS compared to both HDB and LDB in 1989, 2001, and 2014 were $12.62 \%$, $19.43 \%$, and $22.51 \%$, respectively. However, the fragmentation of UGS increased by approximately $100 \%$ in two decades and mainly occurred in areas with higher HDB (Men and Thuy 2017).

\section{Recommendations and strategies to tackle $\mathrm{PM}_{10}$ concentrations and human exposure}

Based on the results of the analysis, the average annual trend of $\mathrm{PM}_{10}$ concentrations was the highest for the first five years and declined in the last 5 years across the 10 years of analysis, except in Klang, which retained higher $\mathrm{PM}_{10}$ concentrations. In terms of exposure and risks of $\mathrm{PM}_{10}$ concentrations to the health of the population, Kuala Lumpur, Petaling and Klang are high-risk districts and dangerous to the community's health. Therefore, several strategies and control measures are suggested as 
guidelines to reduce the impact of $\mathrm{PM}_{10}$ on the population. In terms of PM monitoring, several aspects need to be emphasized comprehensively and improved. The combination of the PM emission inventory and the PM air quality model was necessary to develop the New Malaysia Ambient Air Quality Standard (NMAAQS), which is used as a guideline for impacts on human health. In addition, the comprehensive measurement of PM involves the chemical composition, particle size distribution and precursor gases, especially from motor vehicle emission sources as they are identified as the dominant source of PM. In terms of delivering information to the community, the DOE has developed a complete air quality database (API) on the DOE website, the Air Pollutant Index of Malaysia (APIMS) for each Continuous Air Quality Monitoring (CAQM) station in Malaysia. In addition, the DOE also developed the application MyIPU, which is a mobile application that provides information on the latest API readings at Continuous Air Quality Monitoring (CAQM) stations in Malaysia, based on standard health classifications. Both of these applications have been introduced with the aim of continuously delivering information on air quality that is easily accessible for everyone.

Motor vehicles are the major source of air pollution, particularly in urban areas. In Malaysia, Euro 4M RON97 petrol has been used since September 2015, followed by Euro 4M RON95 in October 2018, while the government has decided to leapfrog from Euro $2 \mathrm{M}$ diesel to Euro 5 diesel in September 2020, and all gasoline stations offer RON95, RON97, and car diesel (Euro 2M/Euro 4M/Euro 5) (Ramlan et al. 2016; Hirota and Kashima 2020). Additionally, on December 1, 2015, the government published the Euro 5 fuel quality specification and regulation, which comes into force in phases between September 2020 and September 2022 for diesel fuel and between September 2025 and September 2027 for gasoline fuel. As a result, even though the price is slightly higher than diesel Euro 2M, all diesel users should switch to diesel Euro 5 to reduce air pollution. Electric cars (EVs) are gaining attention as a better solution in high-energy consumption and pollutant emission issues to ensure sustainable development in cities and transportation systems (Sofia et al. 2020; Lang et al. 2013; Hu et al. 2021). The implementation of strict regulatory vehicle emissions policies and standards has promoted zero-emission vehicles and many countries are introducing policies to increase the production and adoption of EVs (Liao et al. 2017; Sofia et al. 2020).

In addition, Malaysia and Klang Valley must learn from the United Kingdom in emphasizing reducing pollutant emissions from motor vehicles through the formation of integrated and comprehensive plans for implementation measures. The United Kingdom has introduced a National Transport Plan by creating Clean Air Zones (CAZ) by 2020 that involve restrictions on car drivers and motorcyclists from entering the city centre to achieve pollutant emission standards set in Birmingham. In addition, several major cities in the United Kingdom have also formed Low Emission Zone (LEZ) plans in 2020, which focused on efforts to reduce pollutant emissions in terms of fuel, namely Euro 6 for diesel vehicles and Euro 4 for petrol, through restrictions on commercial vehicle users in city centres. In fact, high charges are also imposed on vehicle users when entering city centres, in addition to improving traffic management, to measure and regulate the flow of traffic in and around the city centre (Hull 2020).

The implementation of Green Infrastructure (GI) by governments and stakeholders significantly reduces air pollution problems, especially in urban areas. Greening cities is essential due to the numerous health benefits as well as ecosystem services, as due to the rough texture and wide contact area of leaves, foliage serves as a biofilter of air pollution and improves air quality in urban areas (Chen et al. 2017; Abhijith et al. 2019). Previous studies in China found that trees eliminated 1,261 metric tonnes of pollutants, of which 772 metric tonnes were $\mathrm{PM}_{10}$. Studies in the United Kingdom also found that planting trees on a quarter of the available urban area significantly reduced $\mathrm{PM}_{10}$ concentrations by between 2 and 10\% (Chen et al. 2017).

Also, public awareness is an important key in reducing the impact of air pollution on public health in cities through the education system. The implementation of an environmentally based education system to various groups of the community aims to disclose and provide detailed and up-to-date information to protect and limit public exposure to air pollution. Environmental education needs to be introduced and implemented in detail and practically as well as covering a variety of accurate curricula and learning modules. For example, educational criteria that prioritize public awareness need to be enhanced and introduced to the public using transport services, walking and cycling in the city, which are environmentally friendly practices that can reduce air pollutant emissions.

\section{Conclusion}

The high level of pollution in the Klang Valley can endanger the health of the local urban community. The annual spatial distribution of $\mathrm{PM}_{10}$ in Klang was an average of between 60 and $100 \mu \mathrm{g} / \mathrm{m}^{3}$ from 2000 to 2009. The $\mathrm{PM}_{10}$ concentrations below $60 \mu \mathrm{g} / \mathrm{m}^{3}$ decreased from 2004 to 2009 over the rest of the Klang Valley. In terms of spatial pattern characteristics of annual $\mathrm{PM}_{10}$ concentrations, 
this shows that clustering was formed between all study stations in the Klang Valley, evidenced by positive $z$-score values each year from 2000 to 2009. Furthermore, positive and significant relationships were also recorded between all stations, especially from 2000 to 2003 with higher $z$-score values of 41.31, 43.10, 50.01 and 45.26, respectively. For the next years, 2004 to 2009, lower $z$-score values were recorded, but these still showed significant relationships of $\mathrm{PM}_{10}$ concentrations between all stations through a $p$-value of 0.00 to form a cluster. The effect of clustering between all stations further indicated the existence of a serious hot spot distribution, especially in Klang station at $99 \%$ confidence compared to other stations from 2000 to 2009 and this situation proved that Klang was identified as the hottest district and severely polluted by $\mathrm{PM}_{10}$ in Klang Valley. Apart from Klang, Petaling and Kuala Lumpur are also classified as districts that recorded the highest PWEL values of more than $15 \mu \mathrm{g} / \mathrm{m}^{3}$, as the total cumulative population and $\mathrm{PM}_{10}$ concentrations were significantly higher from 2000 to 2009. Therefore, this situation further found that Klang was a high-risk area to the population for chronic bronchitis among the adult age group due to the long-term exposure, with an estimated proportion of the population affected ranging from 600,001 and reaching up to 900,000 people from 2002 to 2009. Therefore, cooperation between the government, stakeholders and the community especially, is the crucial component to reduce and control $\mathrm{PM}_{10}$ emissions through various strategies and purposeful implementation is required to achieve a sustainable environment and improve the quality of life among the community in Klang Valley.

\section{Abbreviations \\ $\mathrm{PM}_{10}$ : Suspended particles of less than $10 \mu \mathrm{m} ; \mathrm{CO}$ : Carbon monoxide; $\mathrm{NO}_{2}$ : Nitrogen dioxide; $\mathrm{NOx}$ : Nitrogen oxide; $\mathrm{SO}_{2}$ : Sulphur dioxide; $\mathrm{O}_{3}$ : Ozone; DOE: Department of Environment; FTKL: Federal Territory of Kuala Lumpur; GIS: Geographic Information System; IDW: Inverse distance weighted; PWEL: Population-weighted exposure level; RMAQG: Malaysian Ambient Air Quality Guidelines; NMAAQS: New Malaysian Ambient Air Quality Standards; WHO AQG: World Health Organization Air Quality Guidelines.}

\section{Acknowledgements}

We would like to acknowledge the Air Quality Division, Department of Environment Malaysia (DOE) for providing the air pollutant data. Also, special thanks to Universiti Kebangsaan Malaysia and Universiti Putra Malaysia for giving facilities to conduct this study and Dr. Rose Norman for proofreading this manuscript.

\section{Authors' contributions}

Data curation, methodology and analysis: SHMS. Writing —original draft: SHMS; SM and NLFR. Writing — review and editing: MM. Supervision: MM; RA and AFM All authors have read and agreed to the published version of the manuscript.

\section{Funding}

This research did not receive any specific grant from funding agencies in the public, commercial, or not-for-profit sectors.
Availability of data and materials

Not applicable.

\section{Declarations}

Ethics approval and consent to participate

Not applicable.

\section{Consent for publication \\ Not applicable.}

\section{Competing interests}

Not applicable.

\section{Author details}

${ }^{1}$ Centre for Research in Development, Social and Environment (SEEDS), Faculty of Social Sciences and Humanities, Universiti Kebangsaan Malaysia, Bangi, Selangor, Malaysia. ${ }^{2}$ Department of Environment, Faculty of Forestry and Environment, Universiti Putra Malaysia, Serdang, Selangor, Malaysia. ${ }^{3}$ Institute for Environment and Development (LESTARI), Universiti Kebangsaan Malaysia, Bangi, Selangor, Malaysia.

Received: 6 February 2021 Accepted: 13 November 2021

Published online: 26 January 2022

\section{References}

Abas MR, Rahman NA, Omar NYMJ, Maah MJ, Samah AA, Oros DR, Otto A, Simoneit BRT (2004a) Organic composition of aerosol particulate matter during a haze episode in Kuala Lumpur, Malaysia. Atmos Environ 38(25):4223-4241. https://doi.org/10.1016/j.atmosenv.2004.01.048

Abas MRB, Oros DR, Simoneit BRT (2004b) Biomass burning as the main source of organic aerosol particulate matter in Malaysia during haze episodes. Chemosphere 55(8):1089-1095. https://doi.org/10.1016/j.chemosphere. 2004.02.002

Abdul Rashid MZ (2017) Characteristics, trends and spatial distribution of urban migration in Malaysia: a case study of the Klang valley region. UPLanD 2(2):107-127. https://doi.org/10.6092/2531-9906/5261

Abdullah AM, Samah MA, Tham YJ (2012) An overview of the air pollution trend in Klang Valley, Malaysia. Open Environ Sci 6(1):13-19. https://doi. org/10.2174/1876325101206010013

Abdullah S, Napi NNLM, Ahmed AN, Mansor WNW, Mansor AA, Ismail M, Abdullah AM, Ramly ZTA (2020) Development of multiple linear regression for particulate matter $\left(\mathrm{PM}_{10}\right)$ forecasting during episodic transboundary haze event in Malaysia. Atmosphere 11(3):289. https://doi.org/ 10.3390/atmos 11030289

Abhijith KV, Kumar P (2019) Field investigations for evaluating green infrastructure effects on air quality in open-road conditions. Atmos Environ 201:132-147. https://doi.org/10.1016/j.atmosenv.2018.12.036

Afroz R, Hassan MN, Ibrahim NA (2003) Review of air pollution and health impacts in Malaysia. Environ Res 92(2):71-77. https://doi.org/10.1016/ S0013-9351(02)00059-2

Awang MB, Jaafar AB, Abdullah AM, Ismail MB, Hassan MN, Abdullah R, Johan S, Noor H (2000) Air quality in Malaysia: impacts, management issues and future challenges. Respirology 5(2):183-196

Azid A, Juahir H, Ezani E, Toriman ME, Endut A, Abdul Rahman MN, Umar R (2015) Identification source of variation on regional impact of air quality pattern using chemometric. Aerosol Air Qual Res 15:1545-1558. https:// doi.org/10.4209/aaqr.2014.04.0073

Azmi SZ, Latif MT, Ismail AS, Juneng L, Jemain AA (2010) Trend and status of air quality at three different monitoring stations in the Klang Valley, Malaysia. Air Qual Atmos Health 3(1):53-64. https://doi.org/10.1007/ s11869-009-0051-1

Botkin DB, Keller EA (2007) Environmental Science: Earth as a Living Planet. Hoboken, NJ. Wiley. http://bcs.wiley.com/he-bcs/Books?action=index \&itemld=047148816X\&itemTypeld=BKS\&bcsld=2054 Accessed 2 April 2021 
Chen L, Liu C, Zhang L, Zou R, Zhang Z (2017) Variation in tree species ability to capture and retain airborne fine particulate matter $\left(\mathrm{PM}_{2.5}\right)$. Sci Rep 7(1):3206. https://doi.org/10.1038/s41598-017-03360-1

De Mesnard L (2013) Pollution models and inverse distance weighting: Some critical remarks. Comput Geosci 52:459-469. https://doi.org/10.2139/ssrn. 1931636

Department of Environment (DOE) (2015) Malaysia Environmental Quality Report 2015. Department of Environment, Putrajaya, Malaysia

Department of Environment (DOE) (2016) Malaysian Environmental Quality Report 2016. Department of Environment, Putrajaya, Malaysia

Department of Environment (DOE) (2017) Malaysia Environmental Quality Report 2017. Department of Environment, Putrajaya, Malaysia

Department of Environment (DOE) (2018) Malaysia Environmental Quality Report 2018. Department of Environment, Putrajaya, Malaysia

Department of Environment (DOE) (2020) Malaysia Environmental Quality Report 2020. Department of Environment, Putrajaya, Malaysia

Department of Statistics Malaysia (2000) The Population and Housing Census 2000. Department of Statistics Malaysia, Putrajaya, Malaysia

Department of Statistics Malaysia (2010) The Population and Housing Census 2000. Department of Statistics Malaysia, Putrajaya, Malaysia

Douglas JA, Archer RS, Alexander SE (2019) Ecological determinants of respiratory health: examining associations between asthma emergency department visits, diesel particulate matter, and public parks and open space in Los Angeles, California. Prev Med Report. https://doi.org/10.1016/j.pmedr. 2019.100855

Fujii Y, Mahmud M, Tohno S, Okuda T, Mizohata A (2016) A case study of PM2.5 characterization in Bangi, Selangor, Malaysia during the southwest monsoon season. Aerosol Air Qual Res 16(11):2685-2691. https://doi.org/ 10.4209/aaqr.2015.04.0277

Getis A (2008) A history of the concept of spatial autocorrelation: a geographer's perspective. Geogr Anal 40(3):297-309. https://doi.org/10.1111/j. 1538-4632.2008.00727.x

Hanafi NH, Hassim MH, Noor ZZ, Security W, Bahru J (2018) Overview of health impacts due to haze pollution in Johor, Malaysia. J Eng Technol Sci 50(6):818-831. https://doi.org/10.5614/j.eng.technol.sci.2018.50.6.5

Hasan AR, Nair PL (2014) Urbanisation and growth of metropolitan centres in Malaysia. Malays J Econ Stud 51(1):87-101

HEI International Scientific Oversight Committee (2010) Outdoor Air Pollution and Health in the Developing Countries of Asia: A Comprehensive Review. Special Report 18. Health Effects Institute, Boston, MA. https:// www.healtheffects.org/system/files/SR18AsianLitReview.pdf Accessed 19 March 2021

HEI (2020) State of Global Air 2020. Health Effects Institute (HEI), Institute for Health Metrics and Evaluation (IHME). https://www.c40knowledgehub. org/s/article/State-of-Global-Air?language=en_US Accessed 24 July 2020

Hirota K, Kashima S (2020) How are automobile fuel quality standards guaranteed? Evidence from Indonesia, Malaysia and Vietnam. Transp Res Interdiscip Perspect 4:100089. https://doi.org/10.1016/j.trip.2019.100089

Holm J (2018) Hot spot mapping a spatial and methodological approach to analyzing outdoor crimes in Malmo. Department of Human Geography. Lunds Universitet. http://lup.lub.lu.se/student-papers/record/8960295 Accessed 14 Feb 2021

Hu X, Chen N, Wu N, Yin B (2021) The potential impacts of electric vehicles on urban air quality in Shanghai City. Sustainability 13(2):496. https://doi.org/ 10.3390/su13020496

Hull R (2020) As Birmingham plans to stop vehicles driving through the city, we reveal the areas set to ban cars or have a low emission zone within three years. Daily Mail United Kingdom https://www.dailymail.co.uk/ money/cars/article-7882003/Towns-cities-plan-ban-cars-introduce-lowemission-zones.html?ns_mchannel=rss\&ico=taboola_feed Accessed on 25 March 2021

Ivy D, Mulholland JA, Russell AG (2008) Development of ambient air quality population-weighted metrics for use in time-series health studies. J Air Waste Manage Assoc 58(5):711-720. https://doi.org/10.3155/1047-3289. 58.5.711

Jamalani MA, Abdullah AM, Azid A, Ramli M, Baharudin MR, Bose MM, Elhadi RE, Ahmed Ben Youssef KA, Yusuf Gume D (2016) Monthly analysis of $\mathrm{PM}_{10}$ in ambient air of Klang Valley, Malaysia. Malays J Anal Sci 20(5):1159-1170. https://doi.org/10.17576/mjas-2016-2005-23
Kang Y, Cho N, Son S (2018) Spatiotemporal characteristics of elderly population's traffic accidents in Seoul using space-time cube and space-time kernel density estimation. PLoS ONE 13(5):e0196845. https://doi.org/10. 1371/journal.pone.0196845

Khaniabadi YO, Sicard P, Khaniabadi AO, Mohammadinejad S, Keishams F, Takdastan A, Najafi A, De Marco A, Daryanoosh M (2018) Air quality modeling for health risk assessment of ambient $\mathrm{PM}_{10}, \mathrm{PM}_{25}$ and $\mathrm{SO}_{2}$ in Iran. Hum Ecol Risk Assess 25:1298-1310. https://doi.org/10.1080/10807 039.2018 .1487277

Lang J, Cheng S, Zhou Y, Zhao B, Wang H, Zhang S (2013) Energy and environmental implications of hybrid and electric vehicles in China. Energies 6(5):2663-2685. https://doi.org/10.3390/en6052663

Latif MT, Othman M, Idris N, Juneng L, Abdullah AM, Hamzah WP, Khan MF, Nik Sulaiman NM, Jewaratnam J, Aghamohammadi N, Sahani M, Xiang CJ, Ahamad F, Amil N, Darus M, Varkkey H, Tangang F, Jaafar AB (2018) Impact of regional haze towards air quality in Malaysia: a review. Atmos Environ 77:28-44. https://doi.org/10.1016/j.atmosenv.2018.01.002

Liao F, Molin E, Bert van Wee BV (2017) Consumer preferences for electric vehicles: a literature review. Transp Rev 37(3):252-275. https://doi.org/10. 1080/01441647.2016.1230794

Ling OHL, Musthafa SNM, Mohamed N (2014) Air quality and land use in urban region of Petaling Jaya, Shah Alam and Klang, Malaysia. Asian Environ 7(1):134-144. https://doi.org/10.14456/ea.2014.17

Liu Z, Xie M, Tian K, Gao P (2017) GIS-based analysis of population exposure to $\mathrm{PM}_{2.5}$ air pollution - a case study of Beijing. J Environ Sci (China) 59:48-53. https://doi.org/10.1016/j.jes.2017.02.013

Liu S, Wang L, Zhou L, Li W, Pu X, Jiang J, Chen Y et al (2020) Differential effects of fine and coarse particulate matter on hospitalizations for ischemic heart disease: a population-based time-series analysis in Southwestern China. Atmos Environ 224:117366. https://doi.org/10.1016/j.atmosenv. 2020.117366

Mahmud M (2012) Assessment of atmospheric impacts of biomass open burning in Kalimantan, Borneo during 2004. Atmos Environ 78:242-249. https://doi.org/10.1016/j.atmosenv.2012.03.019

Masron T, Yaakob U, Mohd Ayob N, Mokhtar AS (2012) Population and spatial distribution of urbanisation in Peninsular Malaysia 1957-2000. Geografia Malays J Soc Space 8(2):20-29

Men K, Thuy T (2017) A landscape ecological perspective of the impacts of urbanization on urban green spaces in the Klang Valley. Appl Geogr 85:89-100. https://doi.org/10.1016/j.apgeog.2017.06.002

Ministry of Health Malaysia (MOH) (2012) Health Facts 2012. Ministry of Health Malaysia, Health Informatics Centre Planning and Development Division, Putrajaya, Malaysia.

Mira G, Espindola D, Lívio E, Carneiro C, Cardoso A (2017) Four decades of urban sprawl and population growth in Teresina, Brazil. Appl Geogr 79:73-83. https://doi.org/10.1016/j.apgeog.2016.12.018

Mohtar AAA, Latif MT, Baharudin NH, Ahamad F, Chung JX, Othman M, Juneng $L(2018)$ Variation of major air pollutants in different seasonal conditions in an urban environment in Malaysia. Geosci Lett 5:21. https://doi.org/10. 1186/s40562-018-0122-y

Noor NM, Yahaya AS, Ramli NA, Luca FA, Abdullah MMAB, Sandu AV (2015) Variation of air pollutant (particulate matter-PM10) in Peninsular Malaysia study in the southwest coast of Peninsular Malaysia. Revista De Chimie 66(9):1443-1447

Rahman SA, Hamzah MS, Elias MS, Salim NAA, Hashim A, Shukor S, Siong WB, Wood AK (2015a) A long-term study on characterization and source apportionment of particulate pollution in Klang Valley Kuala Lumpur. Aerosol Air Qual Res 15(6):2291-2304. https://doi.org/10.4209/aaqr.2015. 03.0188

Rahman SAR, Ismail SN, Raml MF, Latif MT, Zainal Abidin E, Praveena M (2015b) The assessment of ambient air pollution trend in Klang Valley, Malaysia. World Environ 5(1):1-11. https://doi.org/10.5923/j.env.20150501.01

Ramlan NA, Yahya WJ, Ithnin AM, Hasannuddin AK, Morazni SA, Mazlan NA, Sugeng DA, Bahar ND, Koga T (2016) Performance and emissions of lightduty diesel vehicle fuelled with non-surfactant low grade diesel emulsion compared with a high grade diesel in Malaysia. Energy Convers Manage 130:192-199. https://doi.org/10.1016/j.enconman.2016.10.057

Selangor Department of Agriculture (2011) Annual Report Selangor Department of Agriculture 2011. Selangor Department of Agriculture, Shah Alam, Malaysia 
Sentian J, Jemain MA, Gabda D, Franky H, Wui JCH (2018) Long-term trends and potential associated sources of particulate matter $\left(\mathrm{PM}_{10}\right)$ pollution in Malaysia. WIT Trans Ecol Environ 230:607-618. https://doi.org/10.2495/ AIR180571

Shaadan N, Jemain AA, Latif MT, Deni SM (2015) Anomaly detection and assessment of $\mathrm{PM}_{10}$ functional data at several locations in the Klang Valley, Malaysia. Atmos Pollut Res 6(2):365-375. https://doi.org/10.5094/ APR.2015.040

Shafie SHM, Mahmud M (2020) Urban air pollutant from motor vehicle emissions in Kuala Lumpur, Malaysia. Aerosol Air Qual Res 20:2793-2804. https://doi.org/10.4209/aaqr.2020.02.0074

Shakor AAA, Pahrol MP, Mazeli MI (2020) Effects of population weighting on $\mathrm{PM}_{10}$ concentration estimation. J Environ Public Health 2020:1561823. https://doi.org/10.1155/2020/1561823

Shao KL, Shan C, Yan C, Bing X, Ping C, Xu DX (2016) The effect of pollutional haze on pulmonary function. J Thorac Dis 8(1):E41-E56. https://doi.org/ 10.3978/j.issn.2072-1439.2016.01.18

Sofia D, Gioiella F, Lotrecchiano N, Giuliano A (2020) Mitigation strategies for reducing air pollution. Environ Sci Pollut Res 27:19226-19235. https://doi. org/10.1007/s11356-020-08647-x

Tarmizi SNM, Asmat A, Sumari SM (2014) Temporal and spatial PM 10 concentration distribution using an inverse distance weighted method in Klang Valley, Malaysia. IOP Conf Series Earth Environ Sci 18:012048. https://doi. org/10.1088/1755-1315/18/1/012048

Wang Y, Wild O, Chen H, Gao M, Wu Q, Qi Y, Chen X, Wang Z (2020) Acute and chronic health impacts of $\mathrm{PM}_{2.5}$ in China and the influence of interannual meteorological variability. Atmos Environ 229:117397. https://doi.org/10. 1016/j.atmosenv.2020.117397

WHO (2016) World Health Statistics 2016: Monitoring health for the SDGs. World Health Organization, Geneva https://www.who.int/gho/publicatio ns/world_health_statistics/2016/Annex_B/en/ Accessed 27 July 2020

Ya'acob SH, Mar Iman AH (2018) Comparison of spatial pattern analysis in profiling air pollution phenomena in Peninsular Malaysia. ASM Sci J 11:40-47

Yang H, Peng Q, Zhou J, Song G, Gong X (2020) The unidirectional causality influence of factors on $\mathrm{PM}_{2.5}$ in Shenyang city of China. Sci Rep 10:8403. https://doi.org/10.1038/s41598-020-65391-5

Yu Z, Zhong S, Wang C, Yang Y, Yao G, Huang Q (2017) Mapping comparison and meteorological correlation analysis of the air quality index in mid-eastern China. ISPRS Int J Geo-Inf 6:52. https://doi.org/10.3390/ijgi6 020052

Zhang Y, Xiang Q, Yu C, Yang Z (2020) Asthma mortality is triggered by shortterm exposures to ambient air pollutants: evidence from a Chinese urban population. Atmos Environ 223:117271. https://doi.org/10.1016/j.atmos env.2020.117271

\section{Publisher's Note}

Springer Nature remains neutral with regard to jurisdictional claims in published maps and institutional affiliations.

\section{Submit your manuscript to a SpringerOpen ${ }^{\circ}$ journal and benefit from:}

- Convenient online submission

- Rigorous peer review

- Open access: articles freely available online

- High visibility within the field

Retaining the copyright to your article

Submit your next manuscript at $>$ springeropen.com 